\title{
Proceeding
}

Supplementary Issue: Winter Conferences of Sports Science. International Conference of Engineering, Innovation Technology and

Applied Science.

\section{An exploration of $I Q, E Q$, spiritual quotient (SQ) elements in the human reengineering program (HRP) practices: A study on the drug rehabilitation Centre in Malaysia}

\author{
MOHD ANUAR ARSHAD ${ }^{1}$, MUHAMMAD SALMAN SHABBIR ${ }^{2}$, ARSHAD MAHMOOD $\left.^{1}\right]$, SHAHID KHAN ${ }^{1}$, \\ MOHAMMED ALI BAIT ALI SULAIMAN 3 \\ ${ }^{1}$ School of Management, University of Science, Malaysia \\ 2Department of Management, College of Commerce and Business Administration, Dhofar University, Oman \\ ${ }^{3}$ Department of Business Studies, Salalah College of Technology, Salalah, Oman
}

\begin{abstract}
This study is entitled An Exploration of IQ, EQ and Spiritual Quotient (SQ) Elements in the Human Re-Engineering Program (HRP) Practices: A Study on the Drug Rehabilitation Centre in Malaysia. This study involved four drug rehabilitation centres in Northern Malaysia which are Perak, Penang, Kedah and Perlis. However, the rehabilitation centres involved in this study came from three different states only which are Cure and Care rehabilitation centre (CCRC) Kampung Selamat, Penang, Klinik Cure \& Care 1 Malaysia, Bukit Mertajam, Penang, Cure \& Care rehabilitation centre (CCRC) Batu Kurau, Perak and Cure \& Care Rehabilitation Centre (CCRC) Bukit Chabang, Perlis. This study using Qualitative Method and Exploratory Research. Therefore, to explore the phenomenon an in-depth interview has been conducted with one officer of the CCRC and at least 3 patients of the CCRC. In total, 17 respondents had been interviewed for this research. All the respondents are male. Results of the study showed that approximately only $30 \%$ of the patients recover. However, this figure is still doubtful due to no exact statistic revealed. The reasons why they are failed to sustain themselves after being freed from the CCRC due to peer's factor ( $40 \%)$, low of self-confidence $(30 \%)$ and weak of religious practice (30\%). Family support is one of the main factors contributed to their recovering process as $90 \%$ of the respondents admitted that. Majority of the patients admitted that peers' factor is the main reason they involved with the drug abuse $(50 \%)$ besides self-exploration (30\%) and other factors (20\%). In order to rebuild the self-confidence, rehabilitation centre used multi programs such as religious activity, peer's guidance or group maker (Pembimbing Rakan Sebaya (PRS), and therapy community. This study also revealed that 3 out of 4 rehabilitation centres used more than $50 \%$ of SQ program in their healing process, $20-25 \%$ on $E Q$ activities and IQ activities. Amongst favourite $S Q$ activities are lqra' class, which is learning how to read the Quran, and Halaqah is where they will discuss about religion and do some self-reflection. Family support and religious commitment and practices are the main contributor to patient's recovery survival after they are freed. As a conclusion, healing process in the rehabilitation centre highly influenced with Spiritual Quotient programs besides others. This shows that internal strength gained via religious commitment and attachment besides continuous practices will be a significant factor of the recovering. Keywords: Intelligence Quotient (IQ); Emotional Quotient (EQ); Spiritual Quotient (SQ); Drug rehabilitation centre; Human ReEngineering Program.
\end{abstract}

Cite this article as:

Arshad, M.A., Shabbir, M.S., Mahmood, A., Khan, S., \& Ali Sulaiman, M.A.B. (2020). An exploration of IQ, EQ, spiritual quotient $(\mathrm{SQ})$ elements in the human reengineering program (HRP) practices: A study on the drug rehabilitation Centre in Malaysia. Journal of Human Sport and Exercise, 15(2proc), S417-S428. doi:https://doi.org/10.14198/jhse.2020.15.Proc2.32

Corresponding author. School of Management, Universiti Sains, Malaysia.

E-mail: arshad@usm.my

Supplementary Issue: Winter Conferences of Sports Science. International Conference of Engineering, Innovation Technology and Applied Science.

JOURNAL OF HUMAN SPORT \& EXERCISE ISSN 1988-5202

(c) Faculty of Education. University of Alicante

doi:10.14198/jhse.2020.15.Proc2.32 


\section{INTRODUCTION}

Drug history in Malaysia was begun on the early 19th century. It's come common with the huge growing numbers of Chinese and Indian workers that came to Malaya to work in the tin mines, rubber plantations and pepper estate respectively. Started with the habit of opium smoking by Chinese it's got growing tremendously in this nation. Some smoked it as a medicine to cure aches pains and some of disease such as Diarrhoea, and Malaria. However, at that time, drug is not considered as harmful and there was no regulation and restriction or taboo to the usage of it. In addition, drug also one of the British trading goods. Opium was an important commodity, which the British company forcefully used in exchange for goods such as spices and others Malay Archipelago. It is also used for purchasing tea from China. Based on a contemporary account by H.M. Elmore, Professor Parkinson described the patterns of trade prevailing in the early 19th century in South-East-Asia:

"These opium ships (my emphasis)...from Bengal.. [touched] Junk Ceylon (Ujung Salang: Phuket), Penang, Selangore, Malacca, Lingin, Pelembang, and ... Batavia... At all these ports of call the ships would get rid of her cargo, taking tin, ivory and [Mexican] dollars in exchange. Any cargo left over was then disposed of on the West Coast of Borneo, for gold, and the ship would then collect more tin, and pepper, and proceed to the Straits of Banca to meet the Company's ships, due there about August. These would take on board much of the tin and pepper, on payment of freight, giving a loan of dollars in exchange. The ship was then to buy more tin, pepper, rattan, wax and betel nuts, and then follow the China ships towards the end of September. It was necessary to discharge and load the return cargo with extraordinary speed in order to sail again in November and reach Calcutta in the following month, ready to begin the voyage again".

In 1910, British Government control all the importation sale and distribution of opium. Meanwhile the government licensed all retail shops. In that time, some state government collected their own taxes on opium and while this policy does not change anything on the pattern of it usage. The Geneva Convention on drug held on the 19th Feb 1925, prompted the British to impose restrictions on the sale and consumption of opium. By 1929, the Federated Malay had 52,313 registered as opium users. The numbers was increase in 1941, into 75,000 opium users and it was estimated that the number of users who were not registered are double.

After Malaysia had independence from British on 1957, the abuse and misuse of drug was been the burden for the government at that time. Even though, Malaysia is not 'producing country', it is nevertheless beset by the drug menace. On 19th February 1983, drug was declared as a main threat to the national security. On that reason, government at that time restrict past law and introduce new law about drug. For example; 'The dangerous act 1952', 'drug dependants (Treatment and rehabilitation) 1983 and others.

On the 17th February 1996, cabinet had approved the formation of National Drug Agency (ADK) by combining the anti-drug workers team (PPAD) and medical care treatment and rehabilitation department (BPRD) which is an organization under the ministry of home affairs (KDN) National Drug Agency (MDK) chaired by Y.B Ministry of home affairs and responsible for all aspects of anti-drug activities in this country.

Formation of National Drug Agency is in tune to ensure all the country's endeavours to eradicate the threat of drugs are carried out in organized, standardised manner and with direction in order to create a society that is free from drugs. In 49 years, formation of National Drug Agency (NDA), various initiatives had been done by Agensi Dadah Kebangsaan (ADK). Unfortunately, the vision of ADK for 'drug free Malaysian' is too far to achieve. Facts said, drug addicts in 2010 in Malaysia is 23,642. In addition, numbers show, ADK clearly not 
succeed recuperate addicts involved when in 2007 and 2009 repeated drug addicts are higher than new drug addicts.

\section{Problem statement}

As stated in the introduction part the two main problems in this research are:

- AADK clearly unsuccessful to prevent and cure repeated addicts. Its means AADK syllabus is effective in short term more than long term.

- Big spending by government every year to ensure this country is free from drugs is one burden and liabilities to our economy situations.

\section{Research questions}

1. How far syllabus used by AADK at CCRC build self-confidence to the patient?

2. How element of mind, body and soul considered in the development of the approach and technique in rehabilitant the patient?

3. How the rehabilitant of the patient (mind, body and soul) will be emphasis as approach and technique used in the program.

\section{Research objectives}

1. To explore the approach and technique used in the drug rehabilitation centre in re-build selfconfidence of the patient.

2. To research on the elements of mind, body and soul considered in the development of the approach and technique in rehabilitant the patient.

3. To study the emphasis of rehabilitant of the patient (mind, body and soul) of the approach and technique used in the program.

\section{Purpose of the study}

The purpose of the study is to create or suggesting an effective way to cure and prevent drug addicts in the long term. The study will be using Human Re-Engineering Programmes (HRP) to prevent and cure client in the Drug Rehabilitation Centre. Despite the effectiveness of the programme for the long term, HRP will also giving impact in the aspect to reduce cost of cure clients in Drug Rehabilitation Centre.

\section{METHODS}

The qualitative approach is selected to obtain a detailed understanding of problems. This study deals with 17 respondents in Drug rehabilitation centre in Northern area Malaysia. Using the phenomenological approach as a research strategy to investigate the participatory processes within drug rehabilitation. In-depth interview was conducted from respondents of 4 drug rehabilitation centre to achieve the research objectives of this research.

\section{Research site}

The research area is Drug rehabilitation centre in Northern area (Pulau Pinang, Perak, Kedah and Perlis) In specific;

- $\quad$ Cure \& care rehabilitation centre (CCRC) Kampung Selamat, Pulau Pinang.

- $\quad$ Cure \& care rehabilitation centre (CCRC) Batu Kurau, Perak

- Klinik Cure\& Care 1 Malaysia, Bukit Mertajam

- Cure\& Care rehabilitation centre, Bukit Chabang, Perlis. 


\section{Sample size and Population}

The respondents of this study are the officers and clients of the Drug Rehabilitation centre in the Northern area of Malaysia. The total number of respondents are around 17 people. The director of CCRC:

- 1 officer

- 2 clients in the centre

Database in November 2013 shows that total clients in the sample centres are as below:

- $\quad$ CCRC Kg. Selamat: 313 peoples

- $\quad$ CCRC Batu Kurau: 286 peoples

- CCRC Serdang: 270 peoples

In this section the respondents' demography will be analysed. A summary of the respondents' demography can be found in table 1 . The male respondents account for $100 \%$ which is 17 respondents. Most of respondents are above 35 years old and only 2 from total respondents are below 35 years old. Means, only $11.11 \%$ respondents are below $35 \%$ and $88.89 \%$ is 35 years old and above. Majority of respondents are Malay account for $66.67 \%$ or 12 respondents and followed by Indian which is 4 people which is $22.22 \%$. only one respondent is Chinese and its account $5.55 \% .33 .33 \%$ of respondents are staff at CCRC and the rest $66.67 \%$ are clients in that centre. Most of the respondents' come from northern regions. 3 from respondents are coming from Penang and Kedah, 1 from Perlis and Perak. Unfortunately, 10 respondents are not recorded from which part of regions.

Table 1. Respondent's' demography.

\begin{tabular}{|l|l|l|}
\hline \multicolumn{3}{c}{ Respondents' Demography } \\
\hline \multirow{2}{*}{ Gender } & Male & $100 \%$ \\
\hline \multirow{2}{*}{ Age } & Female & 0 \\
\hline \multirow{3}{*}{ Ethnicity } & Below 35 & $11.11 \%$ \\
& Above 35 & $88.89 \%$ \\
\hline \multirow{5}{*}{ Region } & Malay & $66.67 \%$ \\
& Indian & $22.22 \%$ \\
& Chinese & $11.11 \%$ \\
\hline & Penang & $16.67 \%$ \\
& Kedah & $16.67 \%$ \\
& Perak & $5.55 \%$ \\
& Perlis & $5.55 \%$ \\
& Not record & $55.56 \%$ \\
\hline
\end{tabular}

\section{RESULTS}

This section presents the findings of the study to know the importance of $S Q$ for drugs rehabilitation centre. The first question concerns the approached and technique used in the rehabilitation centre in re-build selfconfidence of the patient. While the second question was regarding elements of mind, body and soul considered in the development of the approach and technique in rehabilitant of the patient and the last question was about the emphasis of rehabilitant of the patient (Mind, Body, Soul) of the approach and technique used in the program. 


\section{Approached and technique used in the rehabilitation centre in re-build self-confidence of the patient} Curing rate for CCRC

Based on Mr Yap Chung Hong, Director of Cure \& Care Clinic at Bukit Mertajam, curing rate for clients have reach $50 \%$. But this rate doesn't have any prove since it's hard to get an accurate figure.

Based on Mr Anuar the director of Batu Kurau Cure and Care Centre (CCRC) clients that failed (we used return as indicator) reach $70 \%$. Means, $70 \%$ clients in Cure and Care Batu Kurau is return clients.

Based on Director of Bukit Chabang Cure \& Care Centre, he said "it's hard to measure an exact number on curing rate. Curing rates means the clients is fully recover after they free from the centre. But from the information they get, their clients still recovery after 6 months they free.

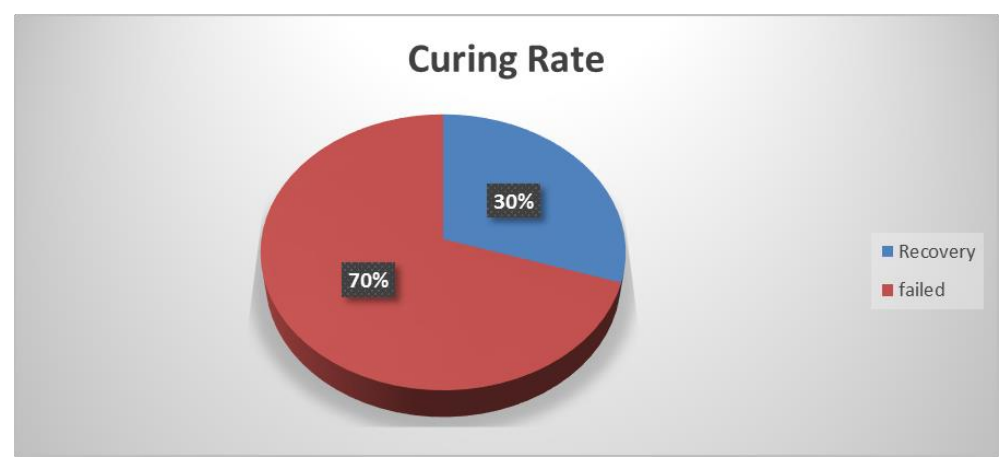

Figure 1. Curing rate.

Determination to leave the drug consumptions

Confident level is very crucial to the patient for them to survive after they free from the centre. So, to know the effectiveness of the program they had followed, we randomly ask the percentage of confident level of them to sustain after they freed.

Table 2. Patients answers.

\begin{tabular}{|l|l|}
\hline Patient 1 (Kampung Selamat) & Yes \\
\hline Patient 2 (Kampung Selamat) & Yes \\
\hline Patient 3 (Bukit Chabang) & Yes $(83 \%)$ \\
\hline Patient 4 (Bukit Chabang) & Yes $(80 \%)$ \\
\hline
\end{tabular}

Unfortunately, statistics show the return drug user is increasing for example $70 \%$ of clients at CCRC Batu Kurau is return clients (second time or third time return) In the interview, Researcher asked about the factor they failed after a month they freed. Thus, researchers conclude the factor by chart.

Based on our interview, Researchers concludes three main factor that contributed to the failure. Failed here mean they are taking drugs again after free. Low Confidence level account $30 \%$ of the factor that they will taking drugs again. Confidence level is about how they think about their self. Most of them feel they are useless and society ignorance them. Patient with low confidence level will failed at this level. The second reason, religious factor also contributes into the failure. Taking easy into the religion command make them fragile than normal people. At the same time, not practise the religion knowledge they had learn in the centre 
also give a bad impact to them. The third reason is peers factor contribute big percentage into the failure of the clients. Some of them very fragile then will surrender in the halfway of their friend persuasion.

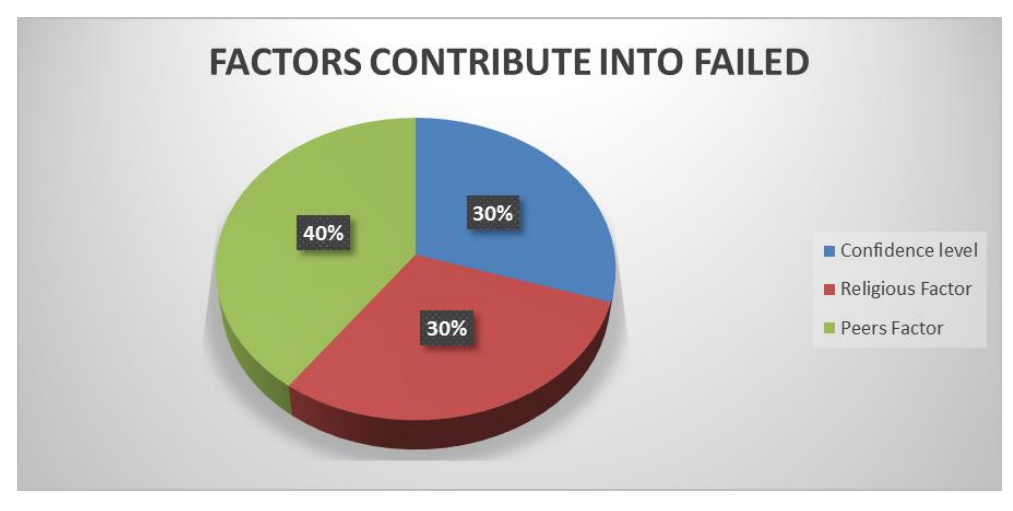

Figure 2. Factors contribute into failed.

Family acceptance

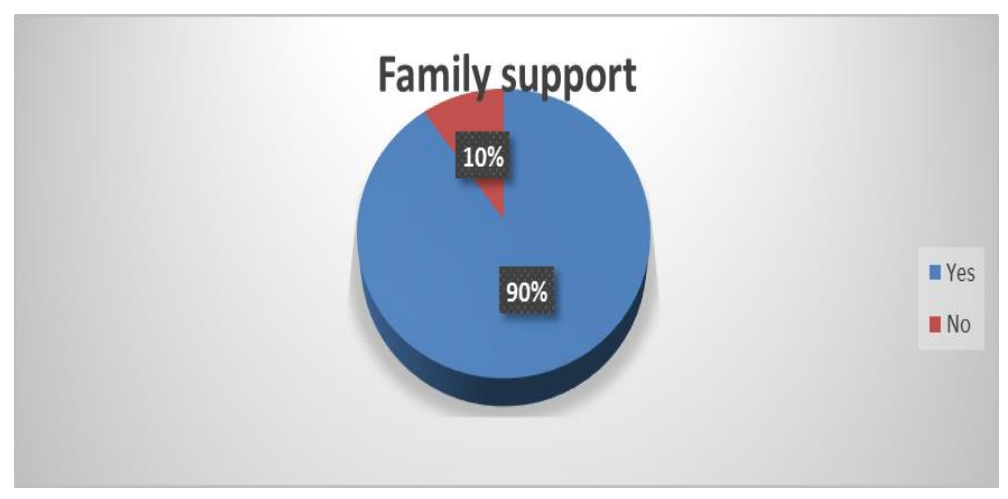

Figure 3. Family support.

It's surprisingly when most of respondent said their family still can accept and still give them support to ensure they have full recovery. Only $10 \%$ of respondent said their family still can't accept them and some of them ended their marriage relationship with divorce.

Activities that rebuild self confidence

It's clearly shows that self-confidence is very crucial in ensuring clients full recovery. Thus, we randomly asking them question on the activities that can enhance their self-confidence.

Table 3. Patients answers.

\begin{tabular}{|l|l|}
\hline Patient 1 (Bukit Mertajam) & Religion activities \\
\hline Patient 2 (Bukit Chabang) & PRS activities \\
\hline Patient 3 (Batu Kurau) & Therapy community \\
\hline Patient 4 (Batu Kurau) & Group Maker \\
\hline
\end{tabular}

The main objective of our research is to study the approach and technique that used by AADK in developing self-confidence of the patient. So, we think it's really important to ask them a question about the activities 
that contribute in building their confidence. We ask randomly the clients. In a nutshell, we can conclude that religion activities, PRS activities, Therapy community and group maker (similar like PRS) give them greater confidence to themselves.

Elements of mind, body and soul considered in the development of the approach and technique in rehabilitant of the patient

Elements of schedule by AADK

Director of CCRC Kampung Selamat said that element Spiritual quotient (SQ), Intelligent Quotient (IQ), Emotional Quotient (EQ) is weighting to SQ. SQ account $50 \%$ from the schedule in the centre. In addition, he also mentioned 8 hours of the schedule is spent to $S Q$ and the rest is for activities that related to IQ and $\mathrm{EQ}$.

The Religious Officer at C\&C Bukit Mertajam also agree with Director of CCRC Kampung Selamat that activities related to the IQ is accounted $50 \%$ from the schedule in the centre. The $25 \%$ activities in the schedule is activities related to IQ and $E Q$.

At the same time, the director of CCRC Bukit Chabang said this centre use SQ approached more than activities related into IQ and $E Q$. After interview, we can conclude that activities that related to $S Q$ in $C C R C$ Bukit Chabang accounted 60\% from the schedule.

Director CCRC Batu Kurau give the opposite opinion. He said that all activities is almost balance. So, respondent said the percentage is about $33 \% 33 \% 33 \%$ respectively.

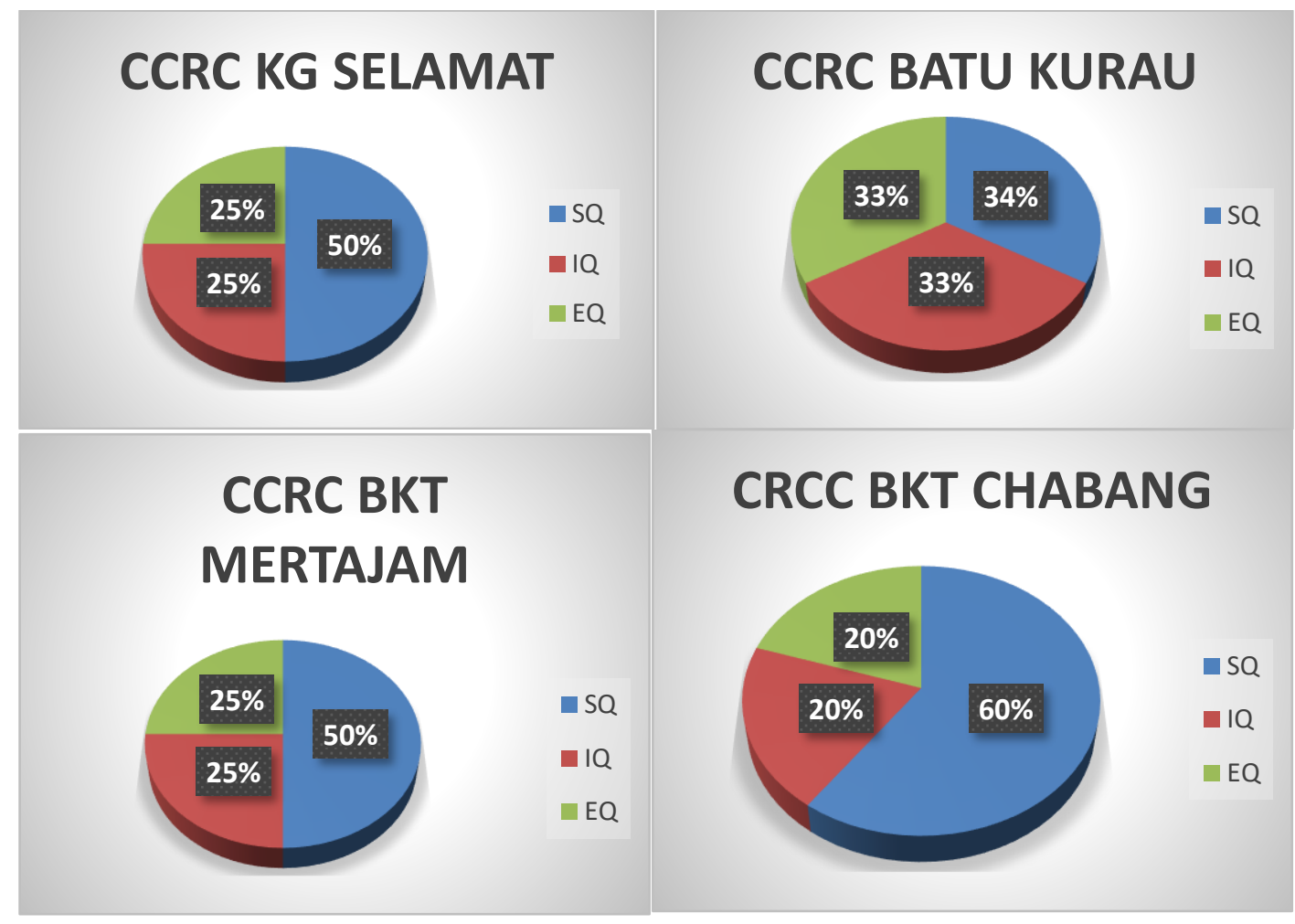

Figure 4. SQ, IQ and EQ charts. 
Spiritual activities implemented in the centre

The spiritual activities implemented in the centre roughly is similar but at the same time there are also differences in activities by the centre. So here we listed the additional spiritual activities (supplement activities) that implement by the centre.

Table 4. Additional spiritual activities.

\begin{tabular}{|l|l|}
\hline CCRC Kampung Selamat & Recite Al Fatihah, 3 Qul's, Selawat (Every Morning), Halaqah, Tazkirah \\
\hline CCRC Batu Kurau & Zikir, Selawat, Halaqah, mandi Jenazah, \\
\hline CCRC Bukit Chabang & $\begin{array}{l}\text { Doa-doa Harian, Baca yaasin, Solat sunat taubat, 10 surah (Basic surah), } \\
\text { Grouping class, Practical class, Halaqah, Evening meeting, Tasmi', Night } \\
\text { (Keagamaan) }\end{array}$ \\
\hline CCRC Bukit Mertajam & $\begin{array}{l}\text { Yaasin (Every day), Fardhu Ain (Class), Dhuha, Practical class, Hafazan } \\
\text { (doa), Kuliah Maghrib. }\end{array}$ \\
\hline
\end{tabular}

The most favourite activities of spiritual activity

Interest is one element we should consider ensuring the program is effective to the clients. We need to know the favourites activities, so that we can enrich the program as in the schedule. For this question we ask the Director or officer in the centre.

C\&C Bukit Mertajam: Based on interview, the officer in this centre said the most favourites spiritual activities in this centre is lqra' class (Practical class). The clients said they really appreciate the chances because they can't get such opportunities outside.

CCRC Bukit Chabang: Based on interview, director of this CCRC said, Halaqah is the most favourites spiritual activities in this centre.

CCRC Batu Kurau: Based on interview, the director of Batu Kurau said that their client can adapt and like all program related into spiritual.

The emphasis of rehabilitant of the patient (Mind, Body, Soul) of the approach and technique used in the program

The factors cause of involvement

It's very crucial to know the factor cause them to involve in drug addiction because of the need to use different approach to cure them.

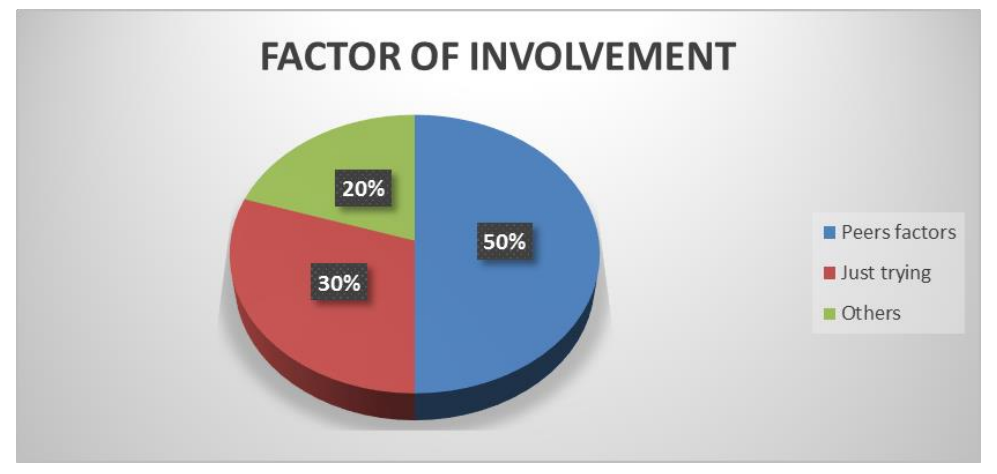

Figure 5. Factor of involvement. 
Peers factors contribute a big share into the involvement of clients to take drugs. Accounted $50 \%$ represent 5 out of 10 respondents that we asked this type of this question involve because of their friends. Just trying also contribute into the involvement of the clients here, and it's accounted about $30 \%$. Finally, others reason such as personal problem such as broken engagement, and to look or be strong also contribute into the taking of the drugs among the clients.

Table 5. Details.

\begin{tabular}{|l|l|}
\hline Clients & Factors cause of involvement \\
\hline Batu Kurau 1 & Peers factors \\
\hline Batu Kurau 2 & Peers factor \\
\hline Bukit Chabang 1 & Others \\
\hline Bukit Chabang 2 & Just trying \\
\hline Bukit Chabang 3 & Others \\
\hline Bukit Mertajam 1 & Just trying \\
\hline Bukit Mertajam & Peers factor \\
\hline Kampung Selamat & Peers factor \\
\hline Kampong Selamat & Peers factor \\
\hline Kampung Selamat & Just trying \\
\hline
\end{tabular}

The factors cause for survival

Based on interview, the factor cause for survival is very important to the researcher to know because from here, we can know the point of their weaknesses. This important especially for the counsellor to remind them when they half of surrender.

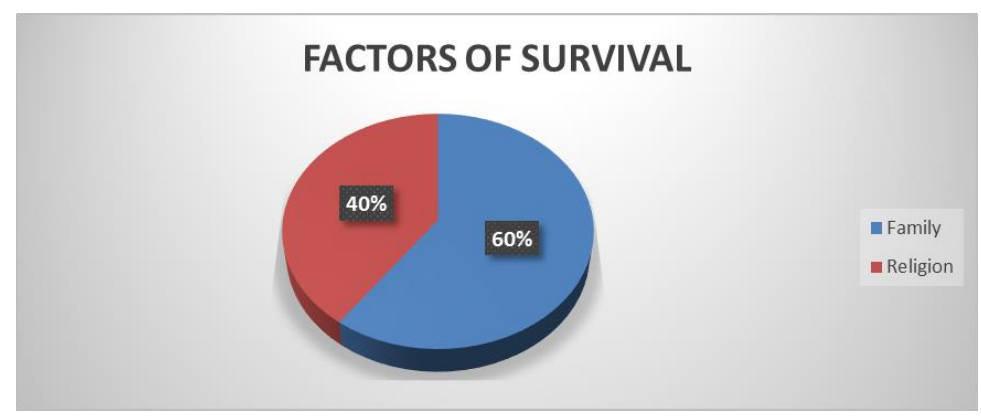

Figure 6. Factors of survival.

Most of them said their family is their backbone or the only reason they still survive to fully recover. It's accounted about $60 \%$. Instead of family, religion factors also give them some spirit to still survive.

Table 6. Factors of survival.

\begin{tabular}{|l|l|}
\hline Batu Kurau 1 & Family supporting \\
\hline Bukit Mertajam 1 & Family supporting \\
\hline Bukit Chabang 1 & Religion factor \\
\hline Bukit Chabang 2 & Religion factor \\
\hline Bukit Chabang & Family supporting \\
\hline Bukit Mertajam 2 & Religion factor \\
\hline Kampung Selamat 1 & Family supporting \\
\hline
\end{tabular}


The planning after free

Most of them choose to find a new place for leaving, start all over again and find religious hope. Some of respondent mention that we can't go back to same place because it will be difficult to control themselves. Some of respondent said they will go to find a religious hope and create their new life. On other hand some of respondent mention that the drug centre give us hope, so it will give service with the centre as a PRS (Pembimbing Rakan Sebaya).

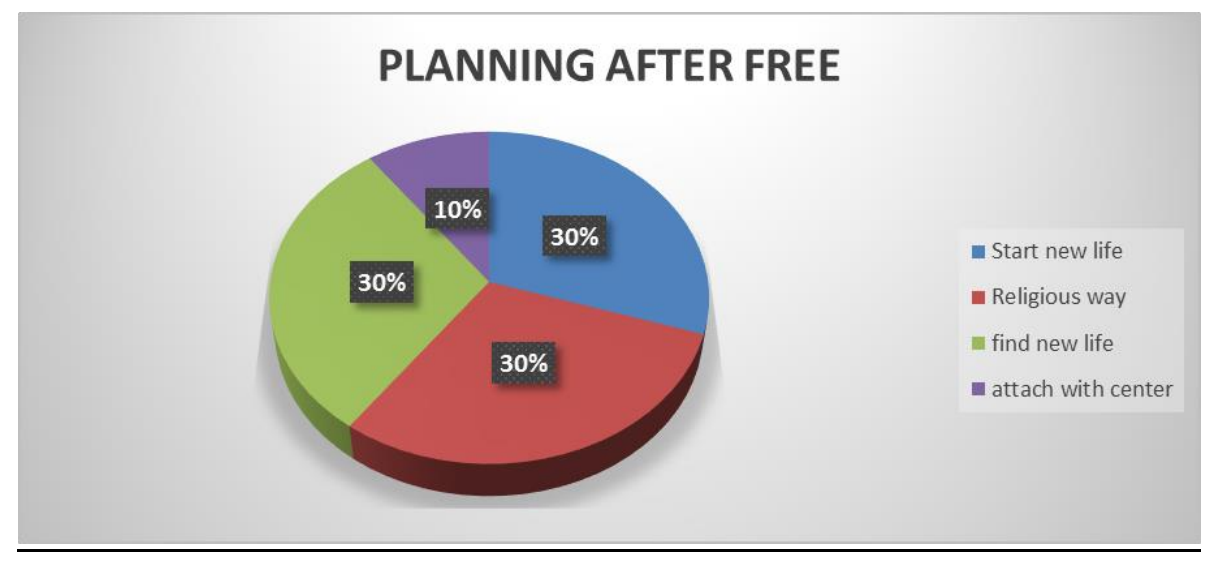

Figure 7. Planning after free.

\section{DISCUSSION}

This study revealed that spiritual activities are the important factor for rehabilitant of the patient. The below three points will explain further.

Approached and technique used in the rehabilitation centre to re-build self-confidence of the patient Based on the previous chapter, we have identified some factors that contribute to the failure of clients after 12 months in the centre. Thus, based on the interview, peers factor contributes almost $40 \%$ of the failure of the clients. Hence, Cure and Care Services Centre (CCSC) that introduced by government is a good place for the clients that feel insecure after they had freed from the centre. As mentioned by AADK, CCSC is one initiative by government to serve aftercare service to the clients after 12 months in CCRC. The main functions of CCSC is to provide cure and care service to the target group through psychosocial program.

Besides, CCSC also contribute the service to references place, sport and recreation place, and RTG Methadone Program as aftercare service to the clients.

\section{Elements of mind, body and soul considered in the development of the approach and technique in rehabilitant the patient}

Spiritual activities including prayers, zikr, Halaqah, selawat, Mathurat and others. On the other hand, activities that related into intelligence quotient contribute almost 5 hours and 30 minutes of the day. Basically, the activities related into intelligence quotient is related into rebuild their strength such as sports, Kawad and others.

Next activities that related into Emotional quotient is about 4 hours and 30 minutes. The activities related into emotional quotient such as relapse prevention, and Music class that touches client's emotion. 


\section{The emphasis of rehabilitant of the patient (mind, body and soul) of the approach and technique used in the program}

The emphasis in the CCRC is more on $S Q$ instead of IQ and EQ. The Officers have a strong believe that $S Q$ had contributed to the greater and faster process of curing while the clients in the centre. Besides that, strong ties with clients family members will also strongly support their emotion and mental to strongly fight with themselves to speed up the curing process. Support, motivation, appreciation and care of the family members becoming a strong booster to help the clients win over the battle. As an evidence 4 out of 7 from the respondent said that they still survive because of their family. In the same time, we also asked about their planning after freed. Most of them said they have a plan after free.

\section{DIRECTIONS FOR FUTURE RESEARCH}

This study can be expanded in many directions for future research. This research can be extended in order to expand body of knowledge and deeper understanding on the components of SQ. It is good if the coverage of CCRC greater to get better idea of the ideal curing method to be uniformly use by the centre. Another aspect to be considered is a study which could explore better support system to help the clients successfully survive after they freed from the centre such as living in one community like Felda or locate them in a place where they can have a job to do besides living with their family and friends. Strong support from religious department or NGO to help them consistent and committed with the religious practices and teaching.

\section{CONCLUSION}

In conclusion, the increasing numbers of clients that return (take more than one) making the process to cure them is more complicated. Besides, the internal problem such as Staff commitment, Staff to client's ratio, no specific field for the motivator, and others also contributed into the failure of this program. Hence, the government should find out the way to solve the problem that mentioned above.

\section{ACKNOWLEDGMENTS}

The authors acknowledge the support of Bridging grant with account no: 304 PMGT 6316039 RCMO University Sains Malaysia as well as The Sumitomo Foundation, Japan in conducting this research.

\section{REFERENCES}

Amrai, K., Farahani, A., Ebrahimi, M., \& Bagherian, V. (2011). Relationship between personality traits and spiritual intelligence among university students. Procedia-Social and Behavioral Sciences, 15, 609-612. https://doi.org/10.1016/i.sbspro.2011.03.149

Faisal, R. F. (2007). The influence of emotional quotient \& spiritual quotient with transformational leadership among managers in Universiti Utara Malaysia. Working Paper. Universitas Andalas. Accessed on October 11, 2010.

Husin, W. N. I. W., Santos, A., Ramos, H. M., \& Nordin, M. S. (2013). The Place of Emotional Intelligence in the 'Intelligence'Taxonomy: Crystallized Intelligence or Fluid Intelligence Factor?. Procedia-Social and Behavioral Sciences, 97, 214-223. https://doi.org/10.1016/..sbspro.2013.10.225

Hill, E. M., \& Maggi, S. (2011). Emotional intelligence and smoking: Protective and risk factors among Canadian young adults. Personality and Individual Differences, 51(1), 45-50. https://doi.org/10.1016/j.paid.2011.03.008 
Kamarudin, A. R. (2007). The misuse of drugs in Malaysia: Past and present. Jurnal Anti Dadah Malaysia, 1, 1-24. AADK Official Site.

Kafetsios, K., \& Zampetakis, L. A. (2008). Emotional intelligence and job satisfaction: Testing the mediatory role of positive and negative affect at work. Personality and individual differences, 44(3), 712-722. https://doi.org/10.1016/i.paid.2007.10.004

Koohbanani, S. E., Dastjerdi, R., Vahidi, T., \& Far, M. H. G. (2013). The relationship between spiritual intelligence and emotional intelligence with life satisfaction among birjand gifted female high school students. Procedia-Social and Behavioral Sciences, 84, 314-320. https://doi.org/10.1016/i.sbspro.2013.06.558

Lynn, A. (2001). The emotional intelligence activity book: 50 activities for promoting EQ at work. Amacom.

Mishra, P. R. A. T. I. M. A., \& Vashist, K. A. M. L. A. (2014). A review study of spiritual intelligence, stress and well-being of adolescents in 21st century. International Journal of Research in Applied Natural and Social Sciences, 2(4), 11-24.

Parker, J. D., Taylor, R. N., Eastabrook, J. M., Schell, S. L., \& Wood, L. M. (2008). Problem gambling in adolescence: Relationships with internet misuse, gaming abuse and emotional intelligence. Personality and Individual differences, 45(2), 174-180. https://doi.org/10.1016/..paid.2008.03.018

Srivastava, A., \& Misra, S. (2012). Is Spriritual Quotient A Beter Tool Of Success: Spirituality In The New World Order. Excel International Journal of Multidisciplinary Management Studies, 2(1).

\section{@) $\Theta \Theta \Theta$}

This work is licensed under a Attribution-NonCommercial-NoDerivatives 4.0 International (CC BY-NC-ND 4.0). 